\title{
Partial Purification and Properties of Cellulase-Free Alkaline Xylanase Produced by Rhizopus stolonifer in Solid- State Fermentation
}

\author{
Antonio José Goulart ${ }^{1}$, Eleonora Cano Carmona ${ }^{2}$ and Rubens Monti ${ }^{{ }^{*}}$ \\ ${ }^{1}$ Universidade Estadual Paulista "Júlio de Mesquita Filho"; Faculdade de Ciências Farmacêuticas; Departamento \\ de Alimentos e Nutrição; Rod. Araraquara-Jaú, Km 1; montiru@fcfar.unesp.br;14801-902; Araraquara - SP - \\ Brazil; ${ }^{2}$ Universidade Estadual Paulista "Júlio de Mesquita Filho"; Instituto de Biociências; Departamento de \\ Bioquímica e Microbiologia; Rua 24-A, 1515; 13500-900, Rio Claro - SP - Brazil
}

\begin{abstract}
Rhizopus stolonifer was cultivated in wheat bran to produce a cellulase-free alkaline xylanase. The purified enzyme obtained after molecular exclusion chromatography in Sephacryl S-200 HR showed optimum temperature as $45^{\circ} \mathrm{C}$ and hydrolysis pHs optima as $\mathrm{pH} 6.0$ and 9.0. Xylanase presented higher Vmax at pH 9.0 (0.87 $\mu \mathrm{mol} / \mathrm{mg} \mathrm{protein})$ than at $\mathrm{pH} 6.0$ and minor $\mathrm{Km}$ at $\mathrm{pH} 6.0(7.42 \mathrm{mg} / \mathrm{mL})$ than at $\mathrm{pH} 9.0$.
\end{abstract}

Key words: alkaline xylanase, Rhizopus stolonifer, solid-state fermentation

\section{INTRODUCTION}

Xylan is the main carbohydrate in the hemicellulosic fraction of the vegetable tissues and forms an interface between the lignin and the other polysaccharides. They are mainly encountered in the secondary cellular wall, and their characteristic of adhesion helps to maintain the integrity of the cellular wall (Prade, 1996). Xylan is found in high quantity in hard wood $(15-30 \%$ of the cellular wall), in annual plants (around 30\%) such as corn, ramie and sugar cane as well as soft wood (10\%) (Haltrich et al., 1996; Kulkarni et al., 1999; Kaya et al., 2000).

Xylanase (1,4- $\beta$-D-xylan xylanohydrolase EC 3.2.1.8) is the major component in a group of enzymes, which act depolymerizing the xylan molecules in monomers, which can be used by bacteria and fungi as a primary source of sugar.
The products of the xylan hydrolysis (xylose, xylobiose, xylotriose and xylo-oligosaccharides) have possible applications in the chemical industry, nutritional industry, functional food and also in the production of alternative artificial sweetener with low rate of calories (xylitol). They can also be converted into liquid fuel and solvents (George et al., 2001). Xylanase has been used in bleaching during the paper production, resulting in reduced use of chemicals and resulting in a better brightness (Christov et al., 1999). It also has applications in the beverage industry, bakery and animal food (Kulkarni et al., 1999; Bhat, 2000). Xylanase has been a key in the maceration of vegetables, recuperation of oil in underground mines, extraction of flavors, pigments, vegetable oils and starch, and increase of the efficiency of production of agriculture silage.

\footnotetext{
Author for correspondence
} 
Rhizopus stolonifer belongs to the Zygomycota Phylum, Zygomycetes Class, Mucorales Order (Guarro et al., 1999; Ribes et al., 2000). Lipase of Rhizopus sp was used by Kolossváry (1996) for the optimization of the hydrolysis activity of the triglycerides. $R$. oligosporus was used by Ikasari and Mitchell (1996) for the production of acid protease in solid fermentation. Cordova (1998) used a strain of $R$. rhizopodiformis for the production of lipase from the sugar cane bagasse. Jin et al. (1999) used $R$. oligosporus for the production of the microbial biomass and glucoamylase from the residual water of starch processing; this fungus is also used in tempe production, a fermented food of Asiatic origin (Sparringa and Owens, 1999). Aikat and Bhattacharyya (2000) used $R$. oryzae for the production of protease in wheat bran medium. However, there is no account for the xylanase production by Rhizopus stolonifer. The aim of this work was to determine some properties of the xylanase produced by this fungus.

\section{MATERIALS AND METHODS}

\section{Microorganism and cultivation conditions}

The strain Rhizopus stolonifer CCT 7417 was isolated in our laboratory. The conidia were obtained from cultures maintained at $2 \%(\mathrm{w} / \mathrm{v})$ agar and 4\% (w/v) oat flour. After inoculation of 1 $\mathrm{mL}$ of suspension $\left(10^{7}\right.$ spores $\left./ \mathrm{mL}\right)$ in a solid medium containing $10 \mathrm{~g}$ of wheat bran and $20 \mathrm{~mL}$ of distilled water, the culture was grown at $35^{\circ} \mathrm{C}$ for 7 days.

After the growth, the medium was filtered in gaze and the filtrate was centrifuged for $20 \mathrm{~min}$. at $4^{\circ} \mathrm{C}$ and $9000 \mathrm{rpm}$. To the filtrate $4 \%(\mathrm{w} / \mathrm{v})$ of kaolin (Sigma) was added and homogenized. After 15 min. at room temperature, it was vacuum filtered and the proteins of the filtrate were concentrated with acetone.

\section{Enzymatic assay and proteins determination}

Xylanase activity was determined through the reducing sugar produced following Miller's method (1959). The assays conditions were $1 \%$ (w/v) birchwood xylan Sigma in $50 \mathrm{mM}$ sodium acetate buffer $\mathrm{pH} 5.0$ at $35^{\circ} \mathrm{C}$. One unit of enzyme was defined as the quantity of enzyme that released $1 \mu \mathrm{mol}$ of reducing sugar per minute. The specific activity was expressed as unit of activity per milligram of protein. The concentration of proteins was determined by Lowry's method modified by Hartree (1972), using bovine serum albumin as standard.

\section{Molecular exclusion chromatography}

Samples concentrated with acetone were applied to a Sephacryl S-200 HR column $(51 \times 1.8 \mathrm{~cm})$ and eluted with $50 \mathrm{mM}$ sodium acetate buffer $\mathrm{pH}$ 5.0. Fractions of $2 \mathrm{~mL}$ were collected with flow rate of $10 \mathrm{~mL} / \mathrm{h}$. Proteins of each fraction were detected by absorbance at $280 \mathrm{~nm}$ and the enzymatic activity was determined. The fractions with xylanase activity were pooled and this sample was used in the subsequent experiments.

\section{Polyacrylamide gel in denaturing conditions}

The sample with xylanase activity from the Sephacryl S-200 HR was submitted to $12 \%$ SDSPAGE, according to Laemmli (1970), using the Amersham Biosciences molecular mass pattern, consisting of phosphorylase b (97 kDa), bovine serum albumin (66 kDa), ovalbumin $(45 \mathrm{kDa})$, carbonic anhydrase $(30 \mathrm{kDa})$, trypsin inhibitor $(20.1 \mathrm{kDa})$ and $\alpha$-lactalbumin (14.4 kDa).

\section{Optimum temperature and $\mathrm{pH}$ determination}

The optimum temperature of birchwood xylan hydrolysis was determined at 22 to $90^{\circ} \mathrm{C}$ in 50 $\mathrm{mM}$ sodium acetate buffer $\mathrm{pH}$ 5.0. The optimum $\mathrm{pH}$ of hydrolysis was determined using Mcllvaine buffers from $\mathrm{pH} 2.9$ to 8.0 and glycine-sodium hydroxide for $\mathrm{pH} 8.6$ to 10.0 at $45^{\circ} \mathrm{C}$.

\section{Kinetic parameters ( $\mathrm{Km}$ and Vmax) determination}

The substract concentrations varied from 0.5 to 20 $\mathrm{mg} / \mathrm{mL}$ in $50 \mathrm{mM}$ sodium acetate buffer $\mathrm{pH} 5.0$ and glycine-sodium hydroxide buffer $\mathrm{pH} 9.0$ at $45^{\circ}$ C.

\section{Chromatographic separation of the hydrolysis products}

The products of the xylan hydrolysis were analyzed by thin-layer chromatography on silica gel (Silica Gel 60 AL TLC Merck), using solvent system composed of ethyl acetate, acetic acid, formic acid and water $(9: 3: 1: 4 \mathrm{v} / \mathrm{v})$, according to Fontana et al., 1988. The hydrolysis products were detected with $0.2 \%$ of orcinol (w/v) in sulfuric acid and methanol (10:90 v/v). Xylose and xylobiose (Sigma) were used as standards. 


\section{RESULTS AND DISCUSSION}

\section{Molecular exclusion chromatography}

Fig. 1 presents the enzymatic activity of the eluted fractions as well as the proteins concentration. Two groups of proteins were separated and identified as P-I (proteins without xylanolytic activity) and P-II (proteins with xylanolytic activity). An increase of $55 \%$ in the xylanase specific activity was reached in the group P-II (Table 1). Monti et al. (1991) reported 169.35 $\mathrm{U} / \mathrm{mg}$ protein for xylanase of Humicola grisea; Christov et al. (1999), using several species of Aspergillus obtained $547.4 \mathrm{U} / \mathrm{mL}$ for a xylanase of A. foetidus (ATCC 14916); Duarte et al. (1999) isolated several strain of bacteria, with $41.1 \mathrm{U} / \mathrm{mg}$ protein for a xylanase of the "B" strain; Ghanem et al. (2000) used several forms for the purification of a xylanase of A. terreus and obtained a final specific activity of $183.29 \mathrm{U} / \mathrm{mg}$ protein. Heck et al. (2002) reported $5.19 \mathrm{U} / \mathrm{mg}$ protein for xylanase of a strain of Bacillus subtilis; Damaso et al. (2002), using Thermomyces lanuginosus (IOC4145), obtained $85 \mathrm{U} / \mathrm{mg}$ protein for the xylanase activity in a filtered culture. Coelho and Carmona (2003) reported $107.43 \mathrm{U} / \mathrm{mg}$ protein for xylanase, using A. giganteus. The specific activity of xylanase determined in our work was lower than the range cited in the literature; however, no cellulase activity was found in the fraction P-II, using cellulose microcrystalline Sigma $1 \%(\mathrm{w} / \mathrm{v})$.

The electrophoresis profile of the samples obtained after molecular exclusion chromatography is shown in Fig. 2, indicating partial purification of the sample P-II. The ion exchange resins DEAE-Trisacryl and S-Sepharose were also used with differente buffers and $\mathrm{pHs}$, however, xylanase did not link to any of them under the assay conditions, suggesting that this enzyme was a glycoprotein (Boyer, 1993). The purification of this enzyme could be done through electroelution technique, used by Monti et al. (2003) to purify the form I xylanase from Humicola grisea var. thermoidea.

\section{Determination of temperature and $\mathrm{pH}$ optimum} The optimum temperature of partially purified xylanase was observed in the interval between 40 and $60^{\circ} \mathrm{C}$ (Fig. 3). Values of optimum temperature of xylanase hydrolysis vary according to the producing microorganism. The xylanase produced by different cultures had different temperature optima, such as for Humicola grisea var. thermoidea presented $70^{\circ} \mathrm{C}$ (Monti et al., 1991); A. versicolor $55^{\circ} \mathrm{C}$ (Carmona et al., 1998). A. terreus $40^{\circ} \mathrm{C}, \quad A$. niger $70^{\circ} \mathrm{C}, \quad B$. stearothermophilus $75^{\circ} \mathrm{C}$. However, 50 to $55^{\circ} \mathrm{C}$ seems to be the range of optimum temperature of xylanases (Uhlig, 1998).

The optimum $\mathrm{pH}$ of xylan hydrolysis was determined at $45^{\circ} \mathrm{C}$, using McIlvaine buffer systems and glycine-sodium hydroxide. The results obtained revealed two optima $\mathrm{pHs}$ clearly different, with maxima at pH 6.0 and 9.0 (Fig. 4). This indicated the presence of more than one xylanases in fraction P-II. The optimum $\mathrm{pH}$ for xylanases cited in the literature varied between 4.0 and 5.5 (Uhlig, 1998); however, some bacterial xylanases showed optimum activity between $\mathrm{pH}$ 6.0 and 7.0. These results are interesting as the thermostable and alkaline xylanases have good scope because the enzymatic bleaching of kraft pulp needs these enzymes with such characteristics (Subramaniyan and Prema, 2000; Duarte et al., 1999; Christov et al., 1999). Thus, the alkaline xylanase studied in this work could be utilized with this purpose.

Table 1 - Specific xylanase activity after molecular exclusion chromatography.

\begin{tabular}{l|c|c|c}
\hline \multirow{2}{*}{ Sample } & Protein & \multicolumn{2}{c}{ Xylanase activity } \\
\cline { 2 - 4 } & $\mathbf{m g} / \mathbf{m L}$ & $\mathbf{U} / \mathbf{m L}$ & U/mg protein \\
\hline Crude extract & $2.23 \pm 0.01$ & $0.82 \pm 0.02$ & $0.37 \pm 0.01$ \\
Sephacryl & $0.16 \pm 0.01$ & $0.09 \pm 0.01$ & $0.57 \pm 0.02$ \\
S-200 HR & & & \\
\hline
\end{tabular}

Results represent the average of three experiments. 


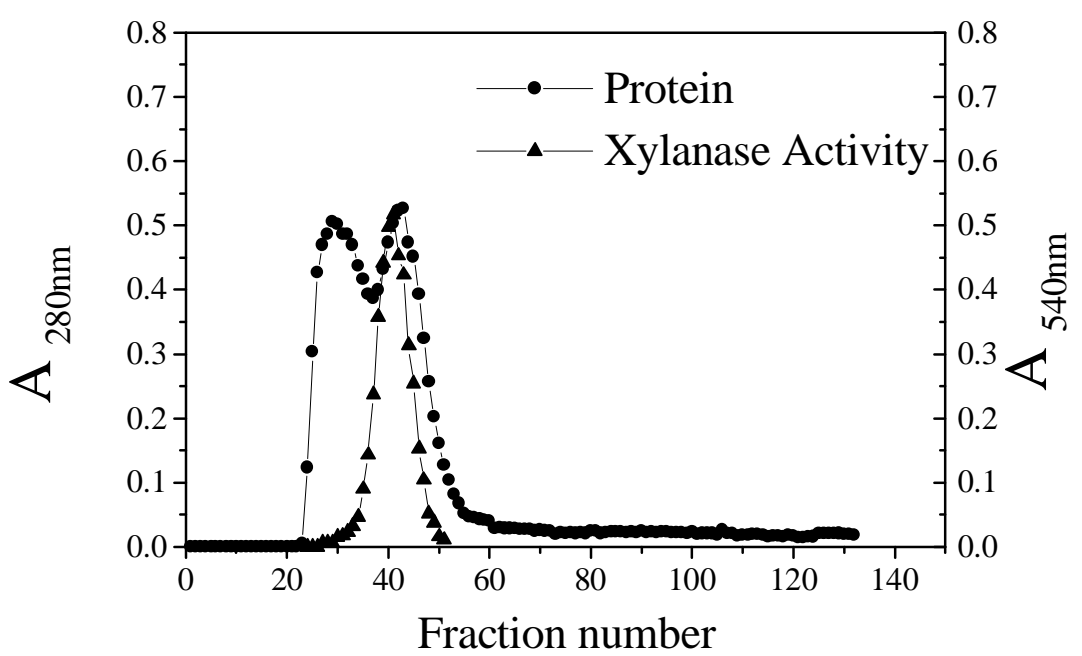

Figure 1 - Elution profile of the proteins and xylanase activity produced by Rhizopus stolonifer in Sephacryl S-200 HR The column $(50 \times 1.8 \mathrm{~cm})$ was eluted with $50 \mathrm{mM}$ sodium acetate buffer $\mathrm{pH} 5.0$; fractions of $2 \mathrm{~mL}$ were collected in a flow rate of $10 \mathrm{~mL} / \mathrm{h}$.

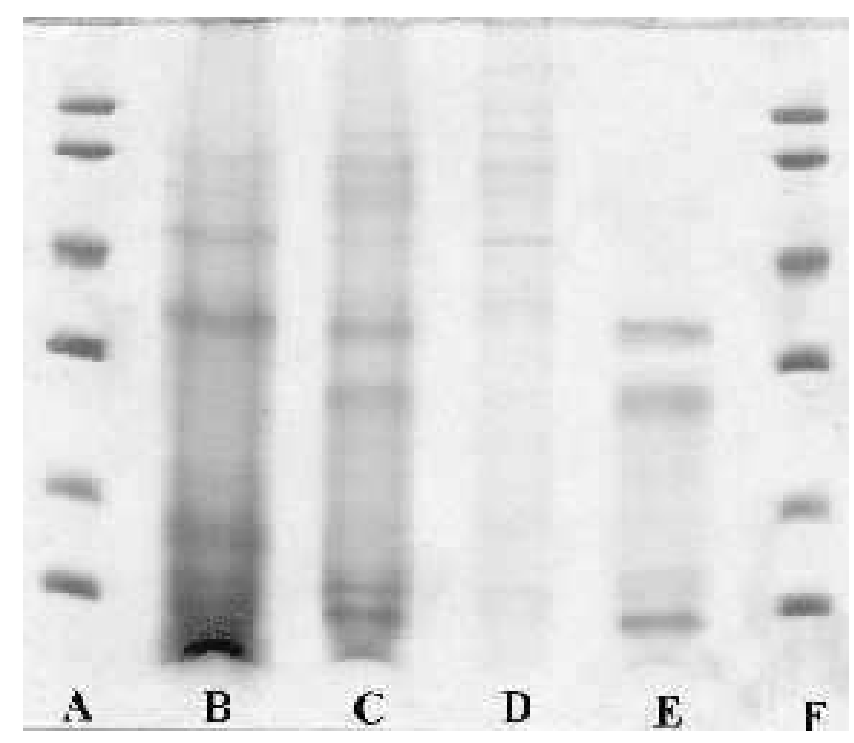

Figure 2 - SDS-PAGE 12\% of samples obtained after Sephacryl S-200 HR. A and F: LMW kit Amersham Biosciences; B: crude extract; C: crude extract precipitated with acetone; D: fraction P-I; E: fraction with xylanolytic activity (P-II). 


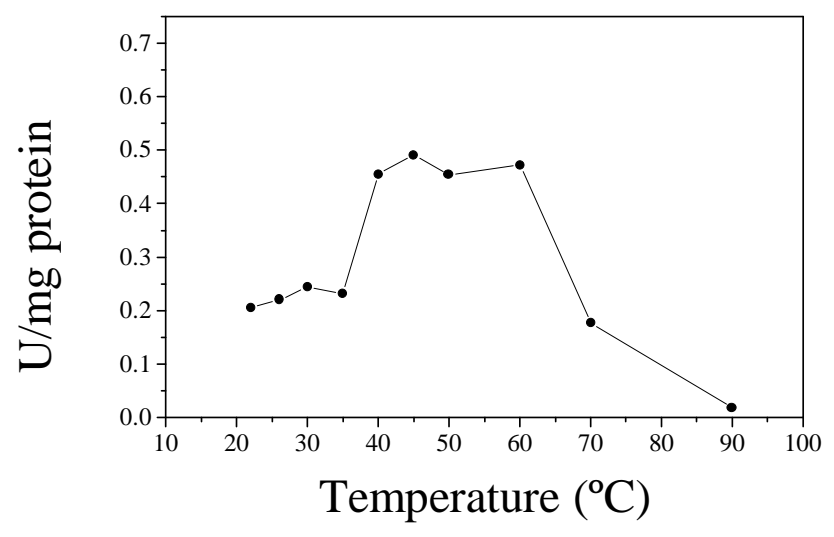

Figure 3 - Optimum temperature determination for the birchwood xylan hydrolysis.

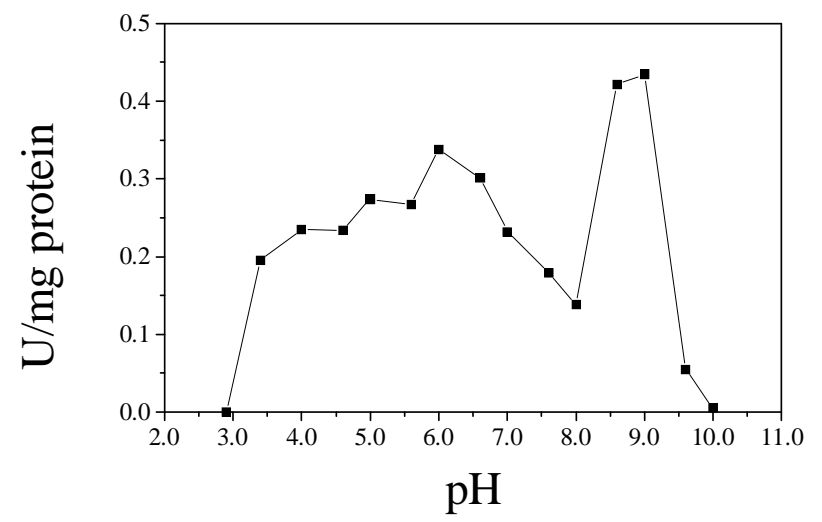

Figure 4 - Optimum pH determination for the birchwood xylan hydrolysis.

\section{Determination of $\mathrm{Km}$ and $\mathrm{Vmax}$}

The results showed the values of $7.42 \mathrm{mg} / \mathrm{mL}$ for $\mathrm{Km}$ and $0.47 \mu \mathrm{mol} / \mathrm{mg}$ protein for Vmax, whereas the values determined in glycine-sodium hydroxide buffer $\mathrm{pH} 9.0$ were $10.0 \mathrm{mg} / \mathrm{mL}$ and $0.87 \mu \mathrm{mol} / \mathrm{mg}$ protein, respectively.

Thin-layer chromatography of the xylan hydrolysis products

The products released at $\mathrm{pH} 6.0$ and 9.0, were xylotriose and xylo-oligosaccharides (Fig. 5). However, after $120 \mathrm{~min}$. at $\mathrm{pH} 9.0$ it was clearly possible to observe the presence of xylobiose, which did not occur at $\mathrm{pH}$ 6.0. These results, once again, suggested the existence of isoforms in P-II fraction. After $120 \mathrm{~min}$. reaction, traces of xylose were obtained, indicating $\beta$-xylosidase activity.
These results showed this enzyme as endoxylanase.

\section{ACKNOWLEDGEMENTS}

Antonio José Goulart thanks Capes - Coordenação de Aperfeiçoamento de Pessoal de Nível Superior for financial support. We thank Dirlene Attili de Angelis for the identification of the strain. 


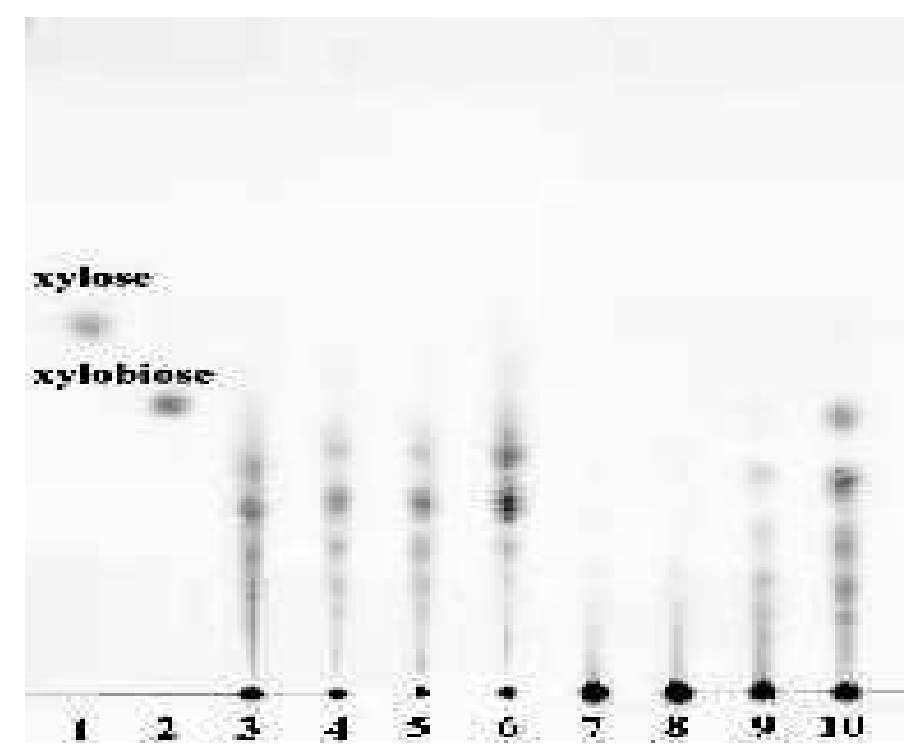

Figure 5 - Chromatographic profile of hydrolysis products of birchwood xylan in pH 6.0 (lines 3 to 6) and 9.0 (lines 7 to 10). Line 1: xylose; line 2: xylobiose; line 3: $10 \mathrm{~min}$; line 4: 20 min.; line 5: 40 min.; line 6: 120 min.; line 7: 10 min.; line 8: 20 min.; line 9: $40 \mathrm{~min}$.; line 10: $120 \mathrm{~min}$.

\section{RESUMO}

Rhizopus stolonifer foi cultivado em meio de farelo de trigo para produzir uma xilanase alcalina celulase-free. Uma amostra parcialmente purificada desta enzima foi obtida após cromatografia de exclusão molecular em Sephacryl S-200 HR. A temperatura ótima de hidrólise determinada $\left(45^{\circ} \mathrm{C}\right)$ está dentro do intervalo citado na literatura $\left(45^{\circ} \mathrm{C}\right.$ a $\left.60^{\circ} \mathrm{C}\right)$ para xilanases microbianas. Quanto ao $\mathrm{pH}$ ótimo, a amostra obtida apresentou atividades máximas em pH 6,0 e 9,0. Estes dados diferem da literatura, uma vez que o $\mathrm{pH}$ ótimo citado para a maioria das xilanases estudadas varia entre 4,0 e 5,5. De acordo com os estudos cinéticos realizados, a xilanase apresentou maior Vmax em pH 9,0 $(0,87$ $\mu \mathrm{mol} / \mathrm{mg}$ proteína) e menor $\mathrm{Km}$ em pH 6,0 (7,42 $\mathrm{mg} / \mathrm{mL}$ ). Os dois $\mathrm{pHs}$ ótimos determinados podem indicar a presença de isoformas desta enzima. Estes dados são interessantes pelo fato de que enzimas xilanolíticas alcalinas celulase-free podem ser utilizadas para o biobranqueamento da polpa na indústria de papel.

\section{REFERENCES}

Aikat, K. and Bhattacharyya, B. C. (2000), Protease extraction in solid state fermentation of wheat bran by a local strain of Rhizopus oryzae and growth studies by the soft gel technique. Process Biochem., 35, 907-914.

Bhat, M. K. (2000), Cellulases and related enzymes in biotechnology. Biotechnol. Advanc., 18, 355-383.

Boyer, R. F. (1993), Modern Experimental Biochemistry. Benjamin/Cummings Publ., Redwood City. pp. 59-114.

Carmona, E. C.; Braga, M. R. B.; Kleiner, A. A. P. and Jorge, J. A. (1998), Purification and biochemical characterization of an endoxylanase from Aspergillus versicolor. FEMS Microbiol. Lett., 166, 311-315.

Christov, L. P.; Szakacs, G. and Balakrishnan, H. (1999), Production, partia 1 characterization and use of fungal cellulase-free xylanases in pulp bleaching. Process Biochem., 34, 511-517.

Coelho, G. D. and Carmona, E. C. (2003), Xylanolytic complex from Aspergillus giganteus: production and characterization. J. Basic Microbiol., 43, 269-277.

Cordova, J.; Nemmaoui, M.; Ismaili-Alaoui, M.; Morin, A.; Roussos, S.; Raimbaut, M. and Benjilali, B. (1998), Lipase production by solid state fermentation of olive cake and sugar cane bagasse. J. Mol. Catal. B - Enzym., 5, 75-78. 
Damaso, M. C. T.; Andrade, C. M. M. C. and Pereira Jr., N. (2002), Production and properties of the cellulasefree xylanase from Thermomyces lanuginosus IOC4145. Braz. J. Microbiol., 33, 333-338.

Duarte, M. C. T.; Portugal, E. P.; Ponezi, A. N.; Bim, M. A. and Tagliari, C. V. (1999), Production and purification of alkaline xylanases. Bioresour. Technol., 68, 49-53.

Fontana, J. D.; Gebara, M.; Blumel, M.; Schneider, H.; Mackenzie, C. R. and Johnson, K. G. (1988), $\alpha-4-O$ methyl-D-glucuronidase component of xylanolytic complexes. Methods Enzymol., 160, 560-571.

George, S. P.; Ahmad, A. and Rao, M. B. (2001), A novel thermostable xylanase from Thermomonospora sp.: influence of additives on thermostability. Bioresour. Technol., 78, 221-224.

Ghanem, N. B.; Yusef, H. H. and Mahrouse, H. K. (2000), Production of Aspergillus terreus xylanase in solid-state cultures: application of the PlackettBurman experimental design to evaluate nutritional requirements. Bioresour. Technol., 73, 113-121.

Guarro, J.; Gené, J. and Stchigel, A. M. (1999), Developments in fungal taxonomy. Clin. Microbiol. Rev., 12, 454-500.

Haltrich, D.; Nidetzky, B.; Kulbe, K. D., Steiner, W. and Zupancic, S. (1996), Production of fungal xylanases. Bioresour. Technol., 58, 137-161.

Hartree, E. F. (1972), Determination of protein: a modification of the Lowry method that gives a linear photometric response. Anal. Biochem., 48, 422-427.

Heck, J. X.; Hertz, P. F. and Ayub, M. A. Z. (2002), Cellulase and xylanase production by isolated amazon Bacillus strains using soybean industrial residue based solid-state cultivation. Braz. J. Microbiol., 33, 213-218.

Ikasari, L. and Mitchell, D. A. (1996), Leaching and characterization of Rhizopus oligosporus acid protease from solid-state fermentation. Enzyme Microb. Technol., 19, 171-175.

Jin, B.; Leeuwen, H. J.; Patel, B.; Doelle, D. W. and $\mathrm{Yu}$, Q. (1999), Production of fungal protein and glucoamylase by Rhizopus oligosporus from starch processing wastewater. Process Biochem., 34, 59-65.

Kaya, F.; Heitmann, J. A. and Joyce, T. W. (2000), Influence of lignin and its degradation products on enzymatic hydrolysis of xylan. J. Biotechnol., 80, 241-247.

Kolossváry, G. J. (1996), Optimization of lipase activity from Rhizopus sp. in triglyceride hydrolysis using a modified simplex method. Process Biochem., 31, 595-600.

Kulkarni, N.; Shendye, A. and Rao, M. (1999), Molecular and biotechnological aspects of xylanases. FEMS Microbiol. Rev., 23, 411-456.

Laemmli, U. K. (1970), Cleavage of structural proteins during the assembly of the head of bacteriophage $\mathrm{T}_{4}$. Nature, 227, 680-685.
Miller, G. L. (1959), Use of dinitrosalicylic acid reagent for determination of reducing sugar. Anal. Chem., 31, 426-429.

Monti, R.; Terenzi, H. F. and Jorge, J. A. (1991), Purification and properties of an extracellular xylanase from the thermophilic fungus Humicola grisea var. thermoidea. Can. J. Microbiol., 37, 675-681.

Monti, R.; Cardello, L.; Custódio, M. F.; Goulart, A. J.; Sayama, A. H. and Contiero, J. (2003), Production and purification of an Endo-1,4-b-xylanase from Humicola grisea var. thermoidea by electroelution. Braz. J. Microbiol., 34, 124-128.

Prade, R. A. (1996), Xylanases: from biology to biotechnology. Biotechnol. Genet. Eng. Rev., 13, 101-131.

Ribes, J. A.; Vanover-Sams, C. L. and Baker, D. J. (2000), Zygomycetes in human disease. Clin. Microbiol. Rev., 13, 236-301.

Sparringa, R. A. and Owens, J. D. (1999), Causes of alkalinization in tempe solid substrate fermentation. Enzyme Microb. Technol., 25, 677-681.

Subramaniyan, S. and Prema, P. (2000), Cellulase-free xylanases from Bacillus and other microorganisms. FEMS Microbiol. Lett., 183, 1-7.

Uhlig, H. (1998), Industrial enzymes and their applications. New York : John Wiley and Sons. pp.37-202.
Received: September 18, 2003; Revised: February 17, 2004; Accepted: September 20, 2004. 